\title{
Classifying the types of evidence produced on the Academia da Cidade Program: a scoping review
}

\section{Classificando os tipos de evidências produzidas sobre o Programa Academia da} Cidade: uma revisão de mapeamento

\section{AUTHOR'S \\ Esdras Henrique Rangel de Melo ${ }^{1}$ (D) Flávio Renato Barros da Guarda ${ }^{1}$ (D) Wallacy Milton do Nascimento Feitosa ${ }^{1}$ Vilde Gomes de Menezes ${ }^{1}$ (D) \\ 1 Federal University of Pernambuco, Post- Graduate Program in Physical Education, Recife, Pernambuco, Brazil. \\ CORRESPONDING \\ Esdras Henrique Rangel de Melo esdrashrm222@gmail.com \\ Rua Venâncio Leonardo Evangelista, no 46, Mustardinha, Recife, Pernambuco, Brasil. ZC: $50760-440$. \\ DOI}

$10.12820 /$ rbafs. $24 \mathrm{e} 0076$

\section{(cc) BY-NC-SA}

This work is licensed under the Creative Commons Attribution-NonCommercial-ShareAlike 4.0 International License.

\begin{abstract}
The Academia da Cidade program (ACP), linked to the Health Secretariat of Recife, Pernambuco since 2002, is a component of health policy focused on Primary Care and aims to promote physical activities, healthy eating and health education. The study aimed to map the scientific production on the ACP. This is a mapping review study with the following steps: (1) clarifying the research question; (2) identifying relevant studies; (3) selecting studies; (4) mapping the studies; (5) summarizing and reporting the results. Searches were made in the Virtual Health Library, Pubmed, Scielo and LILACS databases. Were excluded articles that did not address PAC $(n=17)$, review articles $(n=2)$, and articles that analyzed other programs $(n=2)$ and 16 articles were excluded because they did not present the ACP as the focus of the analysis. Eight studies were identified on this theme. The study identified that most articles focus on types I and II of evidence and that only one article presented the theoretical contribution of policy science in its theoretical scope. We conclude that more research is needed to contribute with more reliable frameworks and methodologies, in line with the public policy analysis process.
\end{abstract}

Keywords: Public policy; Health policy; Health promotion; Motor activities.

RESUMO

O Programa Academia da Cidade (PAC), vinculado à Secretaria de Saúde do Recife, Pernambuco, desde o ano de 2002, é um componente da política de saúde voltado à Atenção Primária e tem como objetivo a promoção da prática de atividades físicas, alimentação saudável e educação para a saúde. O objetivo deste estudo foi mapear a produção científica sobre o PAC. Trata-se de um estudo de revisão de mapeamento com as seguintes etapas: (1) esclarecer a pergunta da pesquisa; (2) identificar estudos relevantes; (3) selecionar estudos; (4) mapear os estudos; (5) resumir e reportar os resultados. Foram realizadas buscas nas bases de dados Biblioteca Virtual de Saúde, Pubmed, Scielo e LILACS. Foram excluídos artigos que não abordavam o PAC $(n=17)$, artigos de revisão $(n=2)$ e artigos que analisaram outros programas $(n=2)$ e 16 artigos foram excluidos por não apresentar $\circ$ PAC como foco da análise. Foram identificados oito artigos científicos sobre o tema. Maior parte dos artigos se concentram nos tipos Ie II de evidências e apenas um artigo apresentou aporte teórico da ciência política em seu escopo teórico. Conclui-se que mais investigaçôes são necessárias para contribuir com frameworks e metodologias mais fidedignas e alinhadas com o processo de análise de politicas públicas.

Palavras-chave: Política pública; Política de saúde; Promoção da saúde; Atividades motoras.

\section{Introduction}

Physical activity programs, especially those with actions in public health, have been highlighted in the past few years ${ }^{1}$. Since then, physical activity (PA) has been seen as an important intervention strategy for health promotion and a modern subject in health policies ${ }^{2-4}$, integrating actions in policies within the Brazilian public health system ${ }^{1}$. Much of it is due to the association between quality of life and physical activity ${ }^{5}$, given there is strong evidence that higher levels of physical activity are directly correlated to improvement in many dimensions of quality of life and that those benefits have been studied since $1950^{6}$, showing a positive relationship between health and physical activity ${ }^{7,8}$.

From that perspective, the Academia da Cidade Program (ACP), linked to the Health Secretariat of Recife since 2002, works as a component of health policy aiming at Primary Care and its goal is to promote physical activity, healthy diet, and health education $^{9}$, where the ACP actions are developed in a system within public open spaces such as parks and plazas ${ }^{10}$. The body of literature on the ACP in Recife is focused in studies on: quality of life, lifestyle, and participant 
satisfaction ${ }^{11-13}$, evaluation of ACP activities ${ }^{14}$, adherence and adhesion of participants ${ }^{10,15}$, effects on the interventions of the ACP in Recife ${ }^{16}$ and articulation between the family health units and the $\mathrm{ACP}^{17}$.

Though PA is recognized as an important theme in public health ${ }^{18}$ and it is a public policy matter ${ }^{19}$, investigations on public health have not presented alignment with policy science theories ${ }^{20}$ and, therefore, do not support evidence connected to the development process of a policy ${ }^{21}$. There are three types of classifications for evidence connecting public policy to PA: Type I evidence linking physical activity and health outcomes (example: diabetes, hypertension); Type II - evidence linking interventions to behaviors related to physical activity (example: environments that influence physical activity); and Type III - evidence linking public policy to physical activity interventions, for example: political agendas, funding, implementation, among others ${ }^{21}$.

That being said, it is necessary to assess the body of evidence produced by studies that analyzed ACP in the city of Recife, highlighting special interest in the three classifications of evidence and whether there is theoretical support from policy science in these studies. Therefore, this literature review aimed to answering the following question: What are the types of evidence produced by studies on ACP in Recife? Moreover, if the analyzed studies had theoretical or methodological support from policy science with a focus on policy analysis.

For screen investigation, it was established that the theoretical or methodological support from policy science by using theoretical frameworks or methodological procedures with epistemological base on policy science. It is important to highlight how this sort of analysis is of great significance for the ACP once this program is linked to a public health policy and, therefore, it is expected that research focusing on thus may clarify processes connected to the execution of local public policy, making the limits and possibilities clearer for governments.

Therefore, this research focused on classifying the scientific literature related to ACP-Recife into three categories of evidence used to develop policies for physical activity as proposed by Rutten et al. ${ }^{21}$.

\section{Methods}

This is a scoping review ${ }^{22}$, also reported in the literature as a mapping review ${ }^{22-24}$. In general terms, the mapping review has been used to synthesize evidence to recognize and clarify the conceptual limits of a field or area of research that have not been determined ${ }^{25,26}$. This re- view followed the methodological criteria established by Levacetal ${ }^{27}$ : (1) to clarify the research question; (2) to identify relevant studies; (3) to select studies; (4) to map studies; (5) to summarize and report results. The search was conducted in the Virtual Health Library, Pubmed, Scielo and LILACS databases.

For the search of articles, the following keywords were used: "Programa Academia da Cidade" and "programas comunitários" and "atividade física" in Portuguese. The search was also conducted with descriptors in English: "Academia da Cidade Program" and "communitary program" and "physical activity".

Then, the title for each selected article was read. Inclusion criteria were: a) original studies; b) conducted in Brazil; c) published in Portuguese or English; d) focus on analyzing the Academia da Cidade Program in Recife. The following were excluded from the analysis: thesis, dissertations, monographs, editorials, and review articles. The search was performed between the months of December 2017 and March 2018 by three researchers who participated in all phases of the study.

For analysis of the studies, the type of evidence was considered (type I, II, or III) and if the analyzed studies used any theoretical support common to policy analysis studies.

\section{Results}

Initially, 90 titles were identified in the databases, with

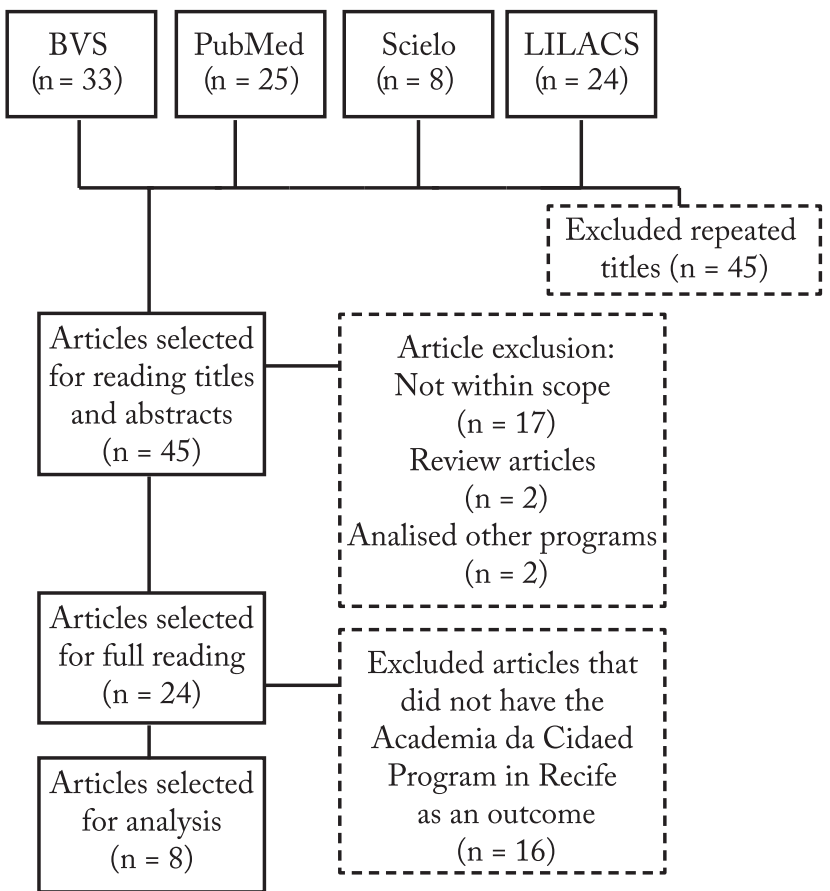

Figure 1 - Review flow chart. 
Table 1 - Mapping of articles selected for analysis.

\begin{tabular}{|c|c|c|c|c|c|c|c|}
\hline \multirow{2}{*}{ Authors } & \multicolumn{5}{|l|}{ PICOS } & \multirow{2}{*}{$\begin{array}{l}\text { Type of evidence } \\
\text { produced }\end{array}$} & \multirow{2}{*}{$\begin{array}{l}\text { Technical } \\
\text { support from } \\
\text { policy science? }\end{array}$} \\
\hline & Population & Intervention & Comparison & Results & Study design & & \\
\hline $\begin{array}{l}\text { Fonte et } \\
\text { al. }^{11}\end{array}$ & $\begin{array}{l}\text { ACP elderly } \\
\text { participants }\end{array}$ & $\begin{array}{l}\text { Leisure PA } \\
\text { Sessions }\end{array}$ & $\begin{array}{l}\text { Sociodemographics and } \\
\text { QoL scores }\end{array}$ & $\begin{array}{l}\text { ACP higher participation } \\
\text { associated with higher } \\
\text { scores in WHO-QOL }\end{array}$ & $\begin{array}{l}\text { Cross- } \\
\text { sectional study }\end{array}$ & Type I & No \\
\hline $\begin{array}{l}\text { Lemos } \\
\text { et al. }{ }^{15}\end{array}$ & ACP participants & $\begin{array}{l}\text { Leisure PA } \\
\text { Sessions }\end{array}$ & ACP adhesion & $\begin{array}{l}>25 \text { months of } \\
\text { participation and weekly } \\
\text { frequency }>3 \mathrm{x} \text { associates } \\
\text { with higher ACP adhesion }\end{array}$ & $\begin{array}{l}\text { Cross- } \\
\text { sectional study }\end{array}$ & Type II & No \\
\hline $\begin{array}{l}\text { Feitosa } \\
\text { et al. }{ }^{12}\end{array}$ & $\begin{array}{l}\text { ACP Female } \\
\text { participants }\end{array}$ & $\begin{array}{l}\text { Leisure PA } \\
\text { Sessions }\end{array}$ & $\begin{array}{l}\text { Perception on improvement } \\
\text { of QoL; Satisfaction with } \\
\text { the PAC }\end{array}$ & $\begin{array}{l}\text { Improved health; pleasure; } \\
\text { social cohesion related to } \\
\text { the PAC-Recife }\end{array}$ & $\begin{array}{l}\text { Cross- } \\
\text { sectional study }\end{array}$ & Type I & No \\
\hline $\begin{array}{l}\text { Lemos } \\
\text { et al. }{ }^{10}\end{array}$ & $\begin{array}{l}\text { ACP current } \\
\text { and former } \\
\text { participants; non- } \\
\text { participants }\end{array}$ & $\begin{array}{l}\text { Leisure PA } \\
\text { Sessions }\end{array}$ & $\begin{array}{l}\text { Adhesion factors and no } \\
\text { adherence }\end{array}$ & $\begin{array}{l}\text { Well-being; healthy } \\
\text { lifestyle and pleasure } \\
\text { related to ACP adhesion }\end{array}$ & $\begin{array}{l}\text { Cross- } \\
\text { sectional study }\end{array}$ & Type II & No \\
\hline $\begin{array}{l}\text { Paes et } \\
\text { al. }^{13}\end{array}$ & $\begin{array}{l}\text { ACP participants } \\
\text { diagnosed with } \\
\text { hypertension }\end{array}$ & $\begin{array}{l}\text { Leisure PA } \\
\text { Sessions }\end{array}$ & $\begin{array}{l}\text { Behaviors related to the } \\
\text { control of risk factors } \\
\text { associated to hypertension }\end{array}$ & $\begin{array}{l}\text { Overweight, excessive } \\
\text { consumption of fat, meats }\end{array}$ & $\begin{array}{l}\text { Cross- } \\
\text { sectional study }\end{array}$ & Type I & $\begin{array}{l}\text { No (but used } \\
\text { governmental } \\
\text { documents) }\end{array}$ \\
\hline $\begin{array}{l}\text { Hallal et } \\
\text { al. }^{14}\end{array}$ & $\begin{array}{l}\text { ACP participants } \\
\text { and non- } \\
\text { participants }\end{array}$ & $\begin{array}{l}\text { Leisure PA } \\
\text { Sessions }\end{array}$ & $\begin{array}{l}\text { Participation, satisfaction, } \\
\text { safety, perception of health }\end{array}$ & $\begin{array}{l}\text { Participation for health } \\
\text { improvement, high level of } \\
\text { satisfaction with the PAC }\end{array}$ & $\begin{array}{l}\text { Cross- } \\
\text { sectional study } \\
\text { with a control } \\
\text { group }\end{array}$ & Type II & $\begin{array}{l}\text { No (but used } \\
\text { governmental } \\
\text { documents) }\end{array}$ \\
\hline $\begin{array}{l}\text { Hallal et } \\
\text { al. }^{28}\end{array}$ & $\begin{array}{l}\text { Professionals } \\
\text { working in PAC }\end{array}$ & $\begin{array}{l}\text { Leisure PA } \\
\text { Sessions }\end{array}$ & $\begin{array}{l}\text { Relevence, difficulties and } \\
\text { envolvement with the ACP } \\
\text { community }\end{array}$ & $\begin{array}{l}\text { Stimuli to PA, difficulty } \\
\text { with physical sctructure, } \\
\text { marketing and human } \\
\text { resources }\end{array}$ & $\begin{array}{l}\text { Cross- } \\
\text { sectional study }\end{array}$ & Type II & $\begin{array}{l}\text { No (but used } \\
\text { governmental } \\
\text { documents) }\end{array}$ \\
\hline $\begin{array}{l}\text { Simões } \\
\text { et al. }{ }^{16}\end{array}$ & $\begin{array}{l}\text { Recife residents } \\
\text { exposed and not } \\
\text { exposed to PAC }\end{array}$ & $\begin{array}{l}\text { Leisure PA } \\
\text { Sessions and } \\
\text { transport PA }\end{array}$ & $\begin{array}{l}\text { Odd ratios: PA/ } \\
\text { sociodemographic; levels of } \\
\text { exposure to PAC; reported } \\
\text { health }\end{array}$ & $\begin{array}{l}>\text { Level of } \mathrm{PA} \text { in men; } \\
\text { participants and former } \\
\text { participants are } 3 \mathrm{x} \text { more } \\
\text { likely to report moderate } \\
\text { to high levels of PA }\end{array}$ & $\begin{array}{l}\text { Cross- } \\
\text { sectional study }\end{array}$ & Type II & $\begin{array}{l}\text { Yes (urban } \\
\text { design, mixed } \\
\text { land use and } \\
\text { transport policy) }\end{array}$ \\
\hline
\end{tabular}

45 being included in the analysis. Then, from the 45 selected titles, those which did not mention the theme of this review were excluded $(n=17)$, review articles $(n=2)$ and articles analyzing other programs $(n=18)$. Therefore, eight articles were analyzed through reading of the full manuscript. The selected studies were summarized for easier identification, categorization, and posterior analysis (Table 1).

When categorizing the types of evidence produced in the articles, it was noted that there were lack of studies with type III evidence. The type II evidence had the higher number of studies $(\mathrm{n}=5)$ followed by type I ( $\mathrm{n}$ $=3$ ) and only one of these studies presented theoretical support common to policy analysis studies.

The studies classified as type I focused on reporting the effects of physical activity sessions offered by the $\mathrm{ACP}-$ Recife in the quality of life of participants ${ }^{11,12}$ and risk factors associated to hypertension in ACP participants ${ }^{13}$.In addition, the type II studies reported how the Academia da Cidade Program relates to healthy lifestyles ${ }^{10}$, effects in the physical activity levels of the population exposed to the $\mathrm{ACP}^{16}$, satisfaction and exposure to the $\mathrm{ACP}^{14}$, adhesion of $\mathrm{ACP}$ participants ${ }^{15}$ and program perception of professionals in the $\mathrm{ACP}^{28}$.

\section{Discussion}

On a mapping review about physical activity public policy using the type of evidence available (Type I, II or III), Rutten et al. ${ }^{21}$ identified that studies focused on type III-those analyzing the formulation, implementation and agenda concerning public policy-were less likely to be found when compared to types I and II.

Even though the studies presented here focused on analyzing some aspect relation to a component of a health public policy, only one study presented theoretical support from policy science which is common to this type of analysis ${ }^{16}$. However, the theoretical approach did not base the main analysis argument reported in the article, only being explained at the end of the analysis when the authors discuss the implications of the evaluated policy.

Even with this field of research presenting a signif- 
icant increase in literature production ${ }^{19}$, a systematic review on the use of policy science theory in research for health promotion ${ }^{20}$ identified lack of theoretical support in studies in public health, which may be an impeding factor for the field of health promotion in assimilating the evidence on public policy research ${ }^{20}$. In the field of public policy in physical activity, this could indicate the understanding on the complexity of policy to implement actions to reduce physical inactivity ${ }^{29}$.

Beyond this analysis, the results show a contradiction in the body of literature analyzed in this review: despite the growth in the number of scientific publications on physical activity public policy, there is no evident discussion on the public policy analysis, where the term itself is not defined or it is seen as a plan or law ${ }^{30}$, even though it is important for researchers to choose the appropriate tools to help in the development of public policies through the evidence to retro feed those interested in a life cycle of a certain program public policy ${ }^{19,31}$.

To distinguish the three types of evidence that support research in health policies focusing on physical activity is useful to highlight the diversity of research in public health and physical activity and point towards knowledge frontiers yet to be investigated. In Brazil, even though studies of this nature have exponentially increased, many have not yet incorporated the theoretical frameworks nor the common methods utilized for policy analysis, which could determine the importance of physical activity as a component in health policy in Brazil, its limitations and frailties, as well as its potentials.

Also, the use of theoretical-methodological designs common to the policy analysis found in the literature would allow the identification of factors that can contribute to the success of the implementation of a health program or policy, revealing more efficient ways to treat physical inactivity, recognized as one of the greatest current challenges in public health.

It is important to highlight that the present study presents limitations. The review presented included only studies emphasizing the Academia da Cidade Program in the city of Recife, therefore, lacking other research that may have analyzed similar initiatives to the public policies in question. Nonetheless, there is a lack of research focusing on the analysis of public policies for physical activity, which can agree with the low prevalence of studies found on this subject.

We conclude more research is necessary to contribute to frameworks and methodologies more reliable and aligned with the process of analysis for public policies.

\section{Conflict of interest}

The authors declare no conflict of interest.

\section{Author contribution}

Melo EHR, concept and writing of manuscript. Guarda FR, critcal review of intelectual content. Feitosa WM, critical review of intelectual content. Menezes VG, following and review of concept and writing of manuscript and approval of final version to be published.

\section{Acknowledgements}

We thank CAPES for funding this research.

\section{References}

1. Becker L, Gonçalves P, Reis R. Programas de promoção da atividade física no Sistema Único de Saúde brasileiro: revisão sistemática. Rev Bras de Ativ Fis Saúde. 2016;21(2):110-22.

2. Ministério da Saúde. A vigilância, o controle e a prevenção das doenças crônicas não-transmissíveis (DCNT) no contexto do Sistema Único de Saúde brasileiro. Brasília, DF: O Ministério; 2005.

3. Global Status Report. On Noncommunicable Diseases 2014: "Attaining the nine global noncommunicable diseases targets; a shared responsibility". Organização Mundial da Saúde. Global Status Report on noncommunicable diseases. Geneva: Attaining the nine global noncommunicable diseases targets; a shared responsibility. 2014. Disponível em: https://apps.who.int/iris /bitstream/handle/ 10665/148114/978924156 4854_eng.pdf;jsession id=9D618173A95CC043D6387D2F9628D762? sequence=1.

4. Maximova K, Hanusaik N, Kishchuk N, Paradis G, O'Loughlin JL. Public health strategies promoting physical activity and healthy eating in Canada: are we changing paradigms? Int J Public Health. 2016;61(5):565-72.

5. Bize R, Johnson JA, Plotnikoff RC. Physical activity level and health-related quality of life in the general adult population: a systematic review. Prev Med. 2007;45(6):401-15.

6. Shuval K, Leonard T, Drope J, Katz DL, Patel AV, MaitinShepard M, et al. Physical activity counseling in primary care: Ins pub health and behav econ. CA: Cancer J Clin. 2017;67(3):233-44.

7. Humphreys BR, McLeod L, Ruseski JE. Physical activity and health outcomes: evidence from Canada. Health Econ.2014;23(1):33-54.

8. Sarma S, Devlin RA, Gilliland J, Campbell MK, Zaric GS. The effect of leisure-time physical activity on obesity, diabetes, high bp and heart disease among Canadians: Evidence from 2000/2001 to 2005/2006. Health Econ. 2015;24(12):1531-47.

9. Mendonça BC, Oliveira JJ, Oliveira AC. Do diagnóstico à ação: experiências em promoção da atividade física programa Academia da Cidade Aracaju: promovendo saúde por meio da atividade física. Rev Bras Ativ Fis Saúde. 2012;14(3):211-16.

10. Lemos EC, Gouveia SG, Luna SC, Silva SG. Programa academia da cidade: descrição de fatores de adesão e não adesão. Rev Bras Ci e Mov. 2016;24(4):75-84.

11. Fonte E, Feitosa PH, de Oliveira Neto LT, Araújo CL, Figueiroa JN, Alves JG. Effects of a physical activity program on the quality of life among elderly people in Brazil. J Family Med Prim Care. 2016;5(1):139-42. 
12. Feitosa WMN, Guarda FRB, Konrad LM, Gonçalves WSF, Martelli PJL, Araújo Júnior JLAC. Users' sperception of actions, improvement in quality of life and satisfaction with the Academia da Cidade Program. Rev Bras Ativ Fis Saúde.2016;21(5):461-69.

13. Paes IM,Fontbonne A, Cesse E. Estilo de vida em hipertensos frequentadores do programa "academia da cidade", Recife, Brasil. Rev Bras Promoç Saúde. 2012;24(4):340-46.

14. Hallal PC, Tenório MCM, Tassitano RM, Reis RS, Carvalho YM, Cruz DK, et al. Avaliação do programa de promoção da atividade física Academia da Cidade de Recife, Pernambuco, Brasil: percepções de usuários e não-usuários. Cad Saude Pub. 2010;26(1):70-8.

15. Lemos EC, Bastos L, Silva G, Luna C, Gouveia G. Factors associated with adherence to the Academia da Cidade Program in Recife. Rev Bras Ativ Fis Saúde. 2016;21(5):470-82.

16. Simões EJ, Hallal PC, Pratt M, Ramos L, Munk M, Damascena W, et al. Effects of a community-based, professionally supervised intervention on physical activity levels among residents of Recife, Brazil. Am J Pub Health, 2009;99(1):68-75.

17. Pajeú R, Cavalcanti J, Moura V, Figueirêdo C, Melo V. Lemos E. Interaction between the Family Health Units and the Academia da Cidade Program in Recife, Northeastern Brazil. Rev Bras Ativ Fis Saúde. 2016;21(5):410-19.

18. Bull FC, Bellew B, Schöppe S, Bauman AE. Developments in National Physical Activity Policy: an international review and recommendations towards better practice. J Sci Med Sport. 2004;7(1):93-104.

19. Rütten A, Abu-Omar K, Gelius $P$, Schow D. Physical inactivity as a policy problem: applying a concept from policy analysis to a public health issue. Health Res Policy Syst. 2013;11(1):1-9.

20. Breton E, De Leeuw E. Theories of the policy process in health promotion research: a review. Health Promot Int. 2010;26(1):82-90.

21. Rütten A, Schow D, Breda J, Galea G, Kahlmeier S, Oppert JM, et al. Three types of scientific evidence to inform physical activity policy: results from a comparative scoping review. Int J Public Health. 2016;61(5):553-63.
22. Arksey H, O’Malley L. Scoping studies: towards a methodological framework. Int J Soc Res Methodol. 2005;8(1):19-32.

23. Anderson S, Allen P, Peckham S, Goodwin N. Asking the right questions: scoping studies in the commissioning of research on the organization and delivery of health services. Health Res Pol Systems. 2008;6(1):7-19.

24. Ehrich K, Freeman GK, Richards SC, Robinson IC, Shepperd S. How to do a scoping exercise: continuity of care. Res Pol Plan. 2002;20(1):25-9.

25. Davis K, Drey N, Gould D. What are scoping studies? A review of the nursing literature. Int J Nurs Stud. 2009;46(10):1386-400.

26. Peters MD, Godfrey CM, Khalil H, McInerney P, Parker D, Soares CB. Guidance for conducting systematic scoping reviews. Int J Evid Basead Healthc. 2015;13(3):141-6.

27. Levac D, Colquhoun H, O'Brien KK. Scoping studies: advancing the methodology. Implement Sci. 2010;5(1):69-78.

28. Hallal PC, Carvalho YM, Tassitano RM, Tenório MC, Warschauer M, Reis R, et al. Avaliação quali-quantitativa do programa Academia da Cidade, Recife (PE): concepções dos professores. Rev Bras Ativ Fis Saúde. 2009;14(1):9-14.

29. Rütten A, Abu-Omar K, Gelius P, Schow D.. Physical inactivity as a policy problem: applying a concept from policy analysis to a public health issue. Health Res Policy Syst. 2013;11(1),9.

30. De Leeuw E. Policies for Health. The effectiveness of their development, adoption, and implementation. In McQueen D, Jones CM. (eds), Global Perspectives on Health Promotion Effectiveness. Springer: New York;2007. p. 51-66.

31. Aro AR, Bertram M,Hämäläinen RM, Valente A. Integrating research evidence and physical activity policy makingREPOPA project. Health Promot Int. 2015;31(2):430-39.

Received: 24/02/2019

Approved: 17/07/2019

\section{Quote this article as:}

Melo EHR, Guarda FRB, Feitosa WM, Menezes VG. Classifying the types of evidence produced on the Academia da Cidade Program: a scoping review. Rev Bras Ativ Fis Saúde. 2019;24:e0076. DOI: 10.12820/rbafs.24e0076 